\title{
Main Factors Determining the Slovak Tax System Performance
}

\author{
Emil Burak, Juraj Nemec
}

\begin{abstract}
The main goal of this paper was to identify the main factors determining the performance of the Slovak tax system. For practical reasons, we decided to deal with all of the potentially relevant dimensions that can be included in the theme - from tax policy to tax administration. The paper is based on primary and secondary data; it combines qualitative and quantitative research methods. The primary data were collected in two rounds, with long-term research about the needs perceived by tax officials and with the "Delphi method". The comparison of the opinions of tax officials and tax experts with the existing evidence serves as the basis for the paper's conclusions and policy proposals. The research shows that the most important areas mentioned by tax officials and experts are relevant (to simplify tax collection, to decrease tax bureaucracy, to provide better information about the tax system to businesses and citizens and to improve tax administration services). However, the second most frequent answer by tax officials (to decrease the tax burden) is somewhat disputable - the research indicates the existence of some level of tax illusion, even at the level of tax administration professionals. The research also reveals the relatively low priority given to the need to increase the level of risk connected with tax evasion, which is surprising because the data clearly indicate a very high level of tax fraud in the country.
\end{abstract}

\section{Keywords}

tax policy, tax administration, Slovakia, determinants

JEL codes: H20, H26 


\section{Introduction}

Existing scientific research frequently deals with the issues of tax-administration performance and optimum tax policies; however, only the second topic is relatively well covered in the Slovak (Czech and Slovak ${ }^{1}$ ) conditions. This situation is rather surprising, considering that there are several university programmes with at least some focus on taxation and public finance in Slovakia. Our paper aims to help to fill this gap - the main goal is to identify the main factors determining the performance of the Slovak tax system, for both of its core dimensions - tax policies and tax administration.

The paper is based on primary and secondary data; it combines qualitative and quantitative research methods. The primary data were collected in two rounds - by long-term research about the needs perceived by tax officials and by the "Delphi method" (questioning a panel of experts). The comparison of the opinions of tax officials and tax experts with the existing evidence serves as the basis for the paper's conclusions and policy proposals.

The term "tax system performance" does not have a fully unified meaning. The first integrated concept of how to construct tax systems was presented by Smith (2005), whose principles of taxation, involved in the canons of taxation, formed the starting point for the study of the theory and practice of tax administration. Justice, certainty, convenience and efficiency are principles that informed the development of contemporary taxation theory. However, this kind of approach needs operationalisation in order to be able to create benchmarks. One interesting framework, provided by Barbone et al. (1999), suggested that the performance of a tax system can be measured via a matrix, where the core areas to be investigated are policy formulation, accountability and service-delivery indicators. Many other authors (e.g. Tanzi 1991, 1996; Gallagher 2005; Das Gupta 2002) do not include accountability as a specific sub-area, focusing on two core levels of tax-system performance: tax policy ("macro-level") and tax administration ("micro-level"). We will continue with this approach for practical reasons.

Both the macro- and micro-levels are frequently investigated by the existing academic and professional literature. However, in literature concerning the macrolevel, the focus is particularly on issues such as the "optimum" tax mix, tax rates, income and the distributive effects of a tax system well covered by well-known textbooks on public finance and taxation (summarised for example by Stiglitz 1989). In the Czech and Slovak conditions, the core textbooks on this topic are Kubatova and Vybihal (2004) and Kubatova (2009).

On the micro-level, academic studies focus particularly on the costs of taxation, and professional studies focus mainly on the capacities of tax administration (such as the contents of the Tax Tribune journal or the OECD tax database series).

1 Despite the split of Czechoslovakia, it is still "one" academic community. 
The costs of taxation may vary over time and place, and they may be analysed in one of two ways. One group of authors uses the term "administrative costs of taxation" to cover only the expenses of the public sector (Sandford 1989). A second group of authors, most notably Stiglitz (1989), divides the costs into the administrative costs of taxation and the indirect expenses of the private sector (the incurred compliance expenses of taxation). Authors adhering to this theory of administrative costs in Czechia and Slovakia include Hamernikova and Kubatova (2000) and Pekova (2002).

There have been many important international studies about this topic (Alm 1996; Evans 2003; Hasseldine and Hansford 2002; Chittenden et al. 2005; Lignier and Evans 2012; Malmer 1995; Mirrlees 1971; Sandford 1989, 1995; Slemrod and Sorum 1984; Susila and Pope 2012; Tran-Nam et al. 2000; Vaillancourt 1987). There have also been some studies in the Central European region (Bayer 2013; Jilkova and Pavel 2006; Klun 2004; Klun and Blazic 2005; Pavel and Vitek 2012, 2015; Solilova and Nerudova 2013; Teperova and Kubantova 2013; Vitek 2008; Vitkova and Vitek 2012).

\section{Research methodology}

Our primary research was conducted in two phases. The long-term research was conducted between February 2013 and February 2016. During this period, we interviewed 282 executive tax officials participating in training at the tax school of the Slovak Financial Office. The requirement for inclusion in the sample was a minimum of four years of practice in tax administration. This large sample size is statistically significant. Our request was rather simple: "Try to define the most significant elements of the possible optimisation of the Slovak tax system." All written responses were processed and summarised by the authors.

Based on the results from the first phase, we created a "matrix" of the main determinants of the performance of the Slovak tax system. This matrix was tested by the one-stage Delphi method. Thirteen questions included in the questionnaire mirrored the structure of the main responses collected from tax officials during our long-term research. Twenty-two experts in political, administrative and academic positions were asked to rank the proposed tax-system performance determinants and also to provide proposals for other determinants and their own comments. This phase took place in April 2016. We received responses from 18 experts, a fully sufficient and significant number of responses.

The secondary research reviewed all of the existing academic literature about different aspects of the Slovak tax-system performance. We also reviewed the opinions of important international organisations (especially the European Commission and OECD documents) about the functionality of the Slovak tax system. Hard 
data and the official statements of major international organisations are related to the collected opinions in the discussion part of this article.

\section{Results from the first phase and their discussion}

Table 1 highlights the main responses (responses with the highest frequency or specific important responses) of the tax officials that were included in the first phase of our research.

\section{Table 1}

Selected responses of tax officials

\begin{tabular}{|l|c|}
\hline \multicolumn{1}{|c|}{ Most frequent responses - suggestions } & Frequency \\
\hline Simplify tax collection, decrease tax bureaucracy & 158 \\
\hline Decrease the tax burden & 145 \\
\hline Provide better information about the tax system to businesses and citizens & 110 \\
\hline Increase the level of risk connected with tax evasion & 86 \\
\hline $\begin{array}{l}\text { It is difficult to optimise the tax policy and the tax system, because there is } \\
\text { no optimum model available }\end{array}$ & 80 \\
\hline $\begin{array}{l}\text { Prevent the transfer of Slovak firms to tax havens by lowering the direct } \\
\text { and indirect tax burden }\end{array}$ & 43 \\
\hline Utilise existing international good practices & 33 \\
\hline Educate taxpayers - taxes are not the worst issue in the world & 31 \\
\hline $\begin{array}{l}\text { Be administratively simple, using low and stable tax rates and providing } \\
\text { effective tax-administration services }\end{array}$ & 27 \\
\hline Improve tax-administration services & 26 \\
\hline Important but infrequent response & Frequency \\
\hline Create a whistle-blowing system for reporting tax evasion & 4 \\
\hline
\end{tabular}

Source: own research

The set of responses indicates that tax officials clearly perceive most of the main problems of the Slovak tax administration - as defined by the academic literature and by the opinion of international organisations. However, it also indicates that the tax officials interviewed are somehow biased and that they may be influenced by political rhetoric. In the following text, we discuss the primary opinions.

\section{Simplify tax collection, decrease tax bureaucracy (+ improve tax- administration services)}

The fact that tax officials perceive the Slovak tax system as complicated, bureaucratic, expensive and not customer-friendly, generating significant tax-administration and tax-compliance costs, can be evaluated as an important opinion that is fully in line with the existing knowledge. 
Current academic studies have documented a critical situation. Pompura (2012) calculated the administrative costs of taxation in Slovakia and estimated them using standard approaches employed by other scientists (see Vitek 2008; Vitkova and Vitek 2012). The results are shown in Table 2.

Table 2

Administrative costs as a percentage of tax revenues, by specified tax

\begin{tabular}{|l|c|c|c|c|c|c|c|c|}
\hline & \multicolumn{7}{|c|}{$\%$} \\
\cline { 2 - 9 } & $\mathbf{2 0 0 4}$ & $\mathbf{2 0 0 5}$ & $\mathbf{2 0 0 6}$ & $\mathbf{2 0 0 7}$ & $\mathbf{2 0 0 8}$ & $\mathbf{2 0 0 9}$ & $\mathbf{2 0 1 0}$ & $\mathbf{2 0 1 1}$ \\
\hline $\begin{array}{l}\text { Income tax of individuals } \\
\text { - Employees }\end{array}$ & $\mathrm{x}$ & 1.77 & 1.96 & 1.64 & 1.48 & 1.62 & 1.81 & 1.65 \\
\hline $\begin{array}{l}\text { Income tax of individuals } \\
\text { - Entrepreneurs }\end{array}$ & 1.98 & 5.86 & 7.64 & 7.92 & 7.04 & 7.92 & 30.76 & 25.51 \\
\hline Corporate income tax & 2.99 & 1.62 & 1.52 & 1.37 & 1.23 & 1.18 & 2.11 & 1.65 \\
\hline $\begin{array}{l}\text { Income tax - lump-sum } \\
\text { form }\end{array}$ & 1.33 & 2.43 & 2.01 & 1.19 & 1.45 & 1.61 & 2.04 & 2.25 \\
\hline Property tax & 0.53 & 1.82 & 1.81 & 19.32 & 14.80 & 14.61 & 13.42 & 31.80 \\
\hline VAT & 3.63 & 1.32 & 1.28 & 1.41 & 1.47 & 1.52 & 1.52 & 1.59 \\
\hline Road Tax & 4.10 & 1.97 & 1.72 & 1.16 & 1.52 & 1.00 & 1.26 & 1.12 \\
\hline
\end{tabular}

Source: Pompura 2012

These data document that tax administration in Slovakia is among the most expensive in the world - see Table 3.

Table 3

Taxation level and administrative costs of taxation: selected countries

\begin{tabular}{|c|c|c|c|c|}
\hline \multirow{2}{*}{$\begin{array}{l}\text { Countries according } \\
\text { to their administrative } \\
\text { costs of taxation }(\%)\end{array}$} & \multicolumn{4}{|c|}{ Countries according to their tax revenues to GDP } \\
\hline & $<20 \%$ & $20-30 \%$ & $30-40 \%$ & Over $40 \%$ \\
\hline-0.60 & & USA & & Sweden \\
\hline $0.61-0.80$ & & Korea & $\begin{array}{l}\text { Ireland, Spain, } \\
\text { New Zealand }\end{array}$ & $\begin{array}{l}\text { Austria, Denmark, } \\
\text { Finland, Germany, } \\
\text { Norway }\end{array}$ \\
\hline $0.81-1.00$ & Mexico & Turkey & & France \\
\hline $1.01-1.20$ & & & $\begin{array}{l}\text { Hungary, } \\
\text { Netherlands, UK }\end{array}$ & Luxembourg \\
\hline $1.21-1.40$ & & & Canada & $\begin{array}{l}\text { Belgium, Czech } \\
\text { Republic }\end{array}$ \\
\hline $1.40+$ & & Japan & $\begin{array}{l}\text { Poland, } \\
\text { Portugal, } \\
\text { Slovakia }\end{array}$ & \\
\hline
\end{tabular}

Source: OECD 2011. 
The existence of high administrative costs has been reflected in the actions of the Slovak government, which in 2012 undertook the large-scale tax-system reform called UNITAS. The main goals of UNITAS are to improve the flow and use of information and to merge the collection of all taxes and social contributions under one administration. The official OECD data (OECD 2015) seem to suggest that UNITAS reforms achieved important results (Table 4).

\section{Table 4}

Administrative costs of taxation: Slovakia

\begin{tabular}{|c|c|c|c|c|c|c|}
\hline \multirow{2}{*}{ Country } & \multicolumn{6}{|c|}{ Administrative costs for tax administration / net revenue collected } \\
& \multicolumn{2}{|c|}{ \% } \\
\cline { 2 - 7 } & $\mathbf{2 0 0 5}$ & $\mathbf{2 0 0 6}$ & $\mathbf{2 0 1 0}$ & $\mathbf{2 0 1 1}$ & $\mathbf{2 0 1 2}$ & $\mathbf{2 0 1 3}$ \\
\hline Slovakia & 2.20 & 2.49 & 3.06 & 3.04 & 1.36 & 1.43 \\
\hline
\end{tabular}

Source: http://www.oecd.org/tax/forum-on-tax-administration/database/

However, such data are hard to believe. The more than $50 \%$ decrease in one year is unrealistic and indicates that data were manipulated by the Slovak Ministry of Finance (or another body responsible for providing input to the OECD) - we will indicate subsequent "post-socialist" manipulations by Slovak public-administration bodies later in the text. In any case, even if 1.43 in 2013 were an accurate figure, it is still comparatively too high.

Cizmarik (2013) estimated the compliance costs of taxation. Because his first calculations were quite negative, he tried to provide other possible alternative calculations. However, for even the most optimistic calculation, the costs incurred to taxpayers are very high; see Table 5.

Table 5

Alternative calculations of compliance costs of income taxation in Slovakia

\begin{tabular}{|l|c|c|c|}
\hline \multicolumn{1}{|c|}{ Alternative } & $\begin{array}{c}\text { CC to tax } \\
\text { revenues - total }\end{array}$ & $\begin{array}{c}\text { CC to tax revenues } \\
- \text { physical persons }\end{array}$ & $\begin{array}{c}\text { CC to tax revenues } \\
- \text { legal persons }\end{array}$ \\
\hline Original results & $73.37 \%$ & $839.02 \%$ & $47.13 \%$ \\
\hline Alternative A & $53.11 \%$ & $242.29 \%$ & $35.98 \%$ \\
\hline Alternative B & $62.36 \%$ & $713.17 \%$ & $40.06 \%$ \\
\hline Alternative C & $40.12 \%$ & $637.04 \%$ & $19.67 \%$ \\
\hline Alternative D & $61.36 \%$ & $734.61 \%$ & $38.29 \%$ \\
\hline Alternative E & $62.99 \%$ & $599.71 \%$ & $44.59 \%$ \\
\hline Alternative A+B+C & $24.69 \%$ & $156.37 \%$ & $12.76 \%$ \\
\hline
\end{tabular}

Source: Cizmarik 2013 
Customer service is an element that is almost missing from Slovak tax administration. Future changes should reflect the fact that there is no system for really effective and binding tax advice from tax offices (ex-ante tax opinion). The existing "tax case law precedents list" may be, but is not necessarily, fully respected by tax authorities or court decisions. Because of this, the decisions of tax officials exerting tax control may differ even with similar cases (Burak and Mazary 2012). This situation creates important levels of critical uncertainty. The recent report by the European Commission (http://ec.europa.eu/europe2020/making-it-happen/country-specific-recommendations/index_en.htm) indicates that existing challenges in Slovakia in this area include: too-frequent changes in tax legislation, complicating life and increasing tax compliance costs; high costs to establish new tax registers (information systems); disconnection from other public-administration registers; missing or very rarely used templates; an overly complicated system of income taxation; and social contributions.

\section{Decrease the tax burden}

This suggested improvement is connected with a frequent criticism of the Slovak tax system as a system creating excessive tax burdens on taxpayers. However, it is only partially compatible with reality. When looking only at income taxes, Slovakia is one of the European countries with really low tax rates. The revenues from income taxation in Slovakia are among the lowest in the European Union. According to official Eurostat data, Slovak income from direct tax revenues in 2012 represented only $5.6 \%$ of the GDP (one of the three lowest), even though more countries have lower implicit tax rates for income taxation (we will return to this finding later in the text). The issue of a high tax burden can be associated with social contributions, which increase labour costs.

\section{Provide better information about the tax system to businesses and citizens}

This response occurred rather frequently, but we do not feel that the situation is so critical in terms of the scope and scale of information provided by the tax system to taxpayers. Unfortunately, Slovakia did not provide data for benchmarking the communication strategies and channels of the national tax administration for the report produced by the Intra-European Organisation of Tax Administrations (IOTA 2013), thus we are not able to provide exact data.

However, this opinion by tax officials might be connected with the fact that the level of fiscal and tax literacy of taxpayers is frequently evaluated as low - as documented, for example, by Cizmarik (2013) and Solilova and Nerudova (2013). Their data confirm the existence of tax illusions. During the research on compliance costs, Cizmarik (2013) asked respondents their opinion about the level of the compliance costs of taxation. The responses were rather surprising: $8 \%$ of respondents felt that 
compliance costs were marginal, and $31 \%$ felt that their level was fully acceptable. Their views of the payroll system were not so positive; even so, $46 \%$ of respondents felt that its costs were acceptable.

\section{Increase the level of risk connected with tax evasion}

Recent data from a report by the European Commission suggest that tax avoidance and tax evasion are still major issues in Slovakia, despite some moderate improvements. The Slovak Ministry of Finance is very positive in reporting improvements, for example in the area of value-added tax, stating that Slovakia received $1.2 \%$ of GDP extra revenues thanks to adopted compliance measures and that the VAT collection gap (the difference between real and potential revenues) decreased to $29.5 \%$. However, the European Commission data report that there is still a $48.6 \%$ VAT collection gap in Slovakia. They also suggest that the too high level of VAT tax returns is an effective signal of tax evasion, as is the fact that in the area of income taxation from 2004 to 2011, approximately $19 \%$ of all companies claimed zero tax duty and approximately $11 \%$ claimed financial loss.

The fact that tax rates in Slovakia are moderate in comparison to other EU countries, but tax revenues are very "small", suggest that the issue of tax evasion and its costs and benefits should be more frequently mentioned by tax officials. Tax evasion in Slovakia is estimated to be very high: official data estimate approximately three billion EUR only for VAT in 2012.

Orviska and Hudson (2003) clearly indicate that tax evasion is a common approach in Slovak business, in part perhaps because the risk of punishment is low. Stieranka et al. (2016) provide a very similar picture in their recent book. For example, Slovakia is the only EU country to apply the principle of "effective regret". Even taxpayers caught by the tax office for evasion can retrospectively pay their tax assessments, plus a $10 \%$ surcharge, and remain "clean", provided they pay up before the final court decision.

Despite all these facts, the tax officials who responded to our survey did not see tax evasion as a core issue, and very few of them provided suggestions for how to cope with it, such as education or whistle blowing.

\section{Policy recommendations and their testing}

Based on the responses of tax officials, the authors drafted a list of core particular measures (areas) determining the performance of the Slovak tax system that should be reflected in the future tax policies. This list was not organised according to main sub-areas, such as tax policy and tax administration, or to sub-levels, such as the idea that communication should be part of a customer-friendly tax administration, because such classification could have misled the experts involved in this phase. 
We decided to test if the thirteen areas proposed are the "core", using an invited pool of tax experts from all levels. The responses of these 18 experts can be accepted as reliable confirmation that the list is fully exhaustive and relevant. The exhaustiveness is confirmed by the fact that none of the experts suggested including an additional area or measure. The relevance is confirmed by the fact that the differences in ranking are very marginal (Figure 1). The highest ranking was received by the need to cope with tax evasion ( 80 points) and the lowest by the need for tax innovations (62 points), which is still a very high priority level (moreover, such a "low" rating may be connected with the fact that the word "innovations" is overused in political rhetoric, sometimes to defend increased bureaucracy). The difference between the first and next-to-last area was only ten points.

Compared to the tax officials from the first phase, the experts from the second phase prioritise the issue of tax evasion, which is a very topical issue for Slovakia, as documented above. Somewhat surprisingly, they also ranked the issue of decreasing the tax burden relatively high. As already explained, income taxation levels in Slovakia are closer to the bottom than to the top of EU approaches; however, most experts claim that social contributions are too high. Another purpose for the high ranking for this area is explained by the statement of one expert, the owner of a tax advisory company:

This issue shall be evaluated from the position of a taxpayer and his dilemmas, as: 'What do I get from the state as compensation for paid taxes? What level and quality of public services is provided? Is the scope of public services delivered by the Slovak state adequate to the tax burden?' The corruption and very low efficiency of the Slovak public administration has a really negative impact on what taxpayers understand by the term 'tax fairness'.

Almost the same opinion was mentioned by a respondent formerly from the academic environment who now works for a private company:

In my opinion the attitudes of taxpayers towards paying taxes are determined by how the state uses tax revenues. The tax rate is a second-level factor. 


\section{Figure 1}

"Better" taxation in Slovakia - main areas

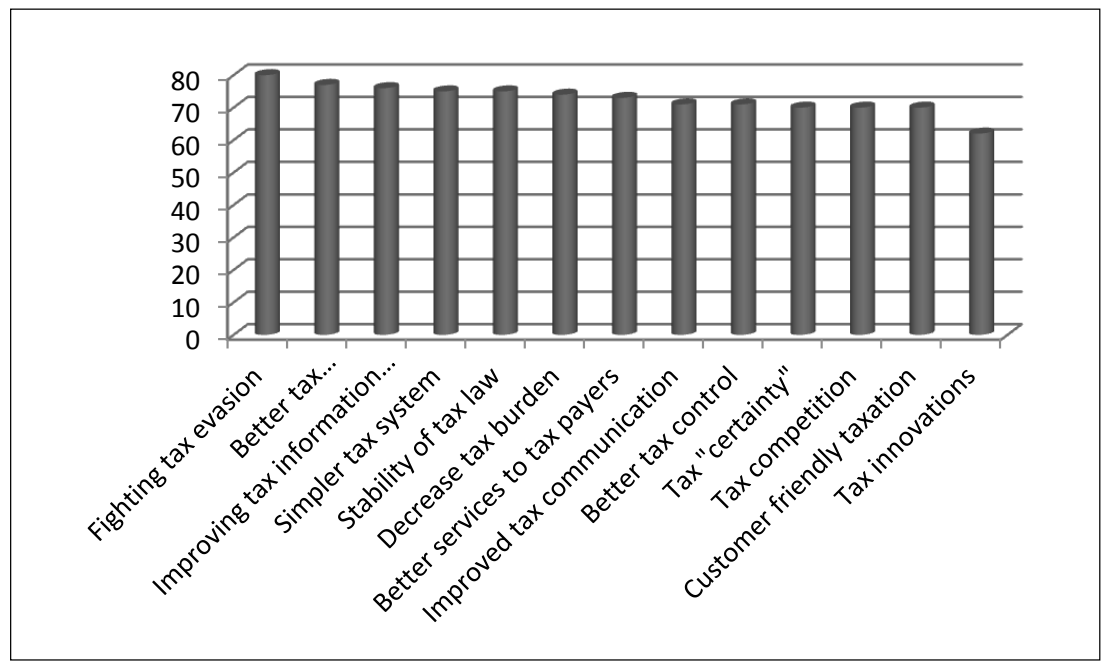

Source: own research

\section{Conclusions}

The main data input for this paper are the responses of tax officials regarding their opinions about the most significant options for optimising the Slovak tax policy and administration. The comparison of their opinions with existing data served as the source for drafting policy recommendations, but also indicates that these tax officials have an imperfect picture of the pros and cons of the current situation.

Some of the most frequent responses, especially to simplify tax collection, to decrease tax bureaucracy, to provide better information about the tax system to businesses and citizens and to improve tax-administration services, are very much in line with the positions of the existing scientific and professional literature. However, the second most frequent answer, to decrease the tax burden, indicates some level of tax illusion even at the level of tax-administration professionals.

One specific concern is the relatively low frequency of the response "increase the level of risk connected with tax evasion". All of the existing data indicate that the level of tax evasion in Slovakia is rather high, with several important factors behind this situation. One of the most significant factors is the low level of risk connected with tax evasion - few cases are discovered and penalised, and moreover Slovakia seems to be the only EU country to apply the principle of "effective regret". Even taxpayers caught by the tax office for evasion can retrospectively pay their tax as- 
sessments, plus a $10 \%$ surcharge, and remain "clean", provided they pay up before the final court decision.

The policy proposals formulated by the authors on the basis of the responses of the tax officials and the critical data-based evaluation of those responses were tested by the simplified one-phase Delphi method. All thirteen proposed areas were confirmed as actual ones by the expert pool. The highest priority was received by the need to cope with tax evasion, which - as documented by this paper - is too high in Slovakia.

\section{Acknowledgements}

This research was completed with support from the research project "Performance Management in Public Administration: Theory and Practice in the Czech Republic and Other CEE Countries", ID (CEP) GA16-13119S.

\section{References}

Alm, J. 1996. “What is an 'Optimal' Tax System?” National Tax Journal 49, 117-133.

Barbone, L., A. Das Gupta, L. De Wulf and A. Hansson. 1999. Reforming Tax Systems. New York, World Bank.

Bayer, O. 2013. "Research of Estimates of Tax Revenue: An Overview." European Financial and Accounting Journal 2013(3), 59-73.

Burak, M. and M. Mazary. 2012. “Tax Optimisation: Selected Issues." Tax Tribune $28,207-211$.

Chittenden, F., S. Kauser and P. Poutziouris. 2005. "PAYE-NIC Compliance Costs: Empirical Evidence from the UK SME Economy." International Small Business Journal 23, 635-656.

Cizmarik, P. 2013. Vyvolane náklady zdanenia. Brno: ESF MU.

Das Gupta, A. 2002. "Central Tax and Administration Reform in the 1990s." In M. G. Rao (ed.). Development, Poverty, and Fiscal Policy. New Delhi: Oxford University Press, 139-173.

Evans, C. 2003. "Studying the Studies: An Overview of Recent Research into Taxation Operating Costs." eJournal of Tax Research 1, 64-82.

Gallagher, M. 2005 "Benchmarking Tax Systems." Public Administration and Development 25, 125-144.

Hamernikova, B. and K. Kubatova. 2000. Verejné finance. Praha: Eurolex Bohemia.

Hasseldine, J. and A. Hansford. 2002. "The Compliance Burden of the VAT: Further Evidence from the UK." Australian Tax Forum 17, 369-388. 
IOTA. 2013. Benchmarking: Pilot Exercise. Available at https://www.iota-tax.org/ publication/iota-booklet-2012-2013 (last accessed on 15.7.2016).

Jilkova, J. and J. Pavel. 2006. Hodnoceni efektivnosti verejnych vydaju na ochranu zivotniho prostredi. Praha: IREAS.

Klun, M. 2004. "Compliance Costs for Personal Income Tax in a Transition Country: The Case of Slovenia." Fiscal Studies 25, 93-104.

Klun, M. and H. Blazic. 2005. "Tax Compliance Costs for Companies in Slovenia and Croatia." Finanzarchiv 61, 418-437.

Kubatova, K. 2009. Danova teorie. Praha: ASPI Publishing.

Kubatova, K. and V. Vybihal. 2004. Optimalizace danoveho systemu CR. Praha: EUROLEX.

Lignier, P. and C. Evans. 2012. "The Rise and Rise of Tax Compliance Costs for the Small Business Sector in Australia." Australian Tax Forum 27, 615-672.

Malmer, H. 1995. "The Swedish Tax Reform in 1990-91 and Tax Compliance Costs in Sweden." In C. Sandford (ed.). Tax Compliance Costs: Measurement and Policy. Bath: Fiscal Publications, 226-262.

Mirrlees, J. A. 1971. "An Exploration in the Theory of Optimum Income Taxation." The Review of Economic Studies 38, 175-208.

OECD. 2011, 2015. Tax Administration in OECD and Selected Non-OECD Countries: Comparative Information Series. Paris: Organization for Economic Cooperation and Development.

Orviska, M. and J. Hudson. 2003. "Tax Evasion, Civic Duty and the Law Abiding Citizen." European Journal of Political Economy 19, 83-102.

Pavel, J. and L. Vitek. 2012. "Transaction Costs of Environmental Taxation: The Administrative Burden." In J. E. Milne and M. S. Andersen (eds). Handbook of Research on Environmental Taxation. Cheltenham: Edward Elgar, 273-282.

Pavel, J. and L. Vitek. 2015. "Vyvolane naklady danoveho systemu v ČR." Politicka ekonomie 63, 317-330.

Pekova, J. 2002, Verejne finance - uvod do problematiky. Praha: ASPI.

Pompura, L. 2012. Hodnotenie a meranie výkonnosti daňovej správy: administratívne náklady zdanenia. Brno, ESF MU.

Sandford, C. 1989. Administrative and Compliance Costs of Taxation. London, Fiscal Publications.

Sandford, C. 1995. Tax Compliance Costs: Measurement and Policy. Bath: Fiscal Publications. 
Slemrod, J. R. and N. Sorum. 1984. "The Compliance Cost of the U.S. Individual Income Tax System.” The National Tax Journal 37, 461-474.

Smith, A. 2005. Inquiry into the Nature and Causes of the Wealth of Nations. Philadelphia: The Pennsylvania State University.

Solilova, V. and D. Nerudova. 2013. "Transfer Pricing: General Model for Tax Planning." Ekonomicky casopis 61, 597-617.

Stieranka, J., M. Sabayova and J. Simonova. 2016. Daňové úniky a daňová kriminalita $v$ Slovenskej republike. Bratislava: EPOS.

Stiglitz, J. E. 1989. Economics of the Public Sector. New York: Norton.

Susila, B. and J. Pope. 2012. "The Tax Compliance Costs of Large Corporate Taxpayers in Indonesia." Australian Tax Forum 27, 719-772.

Tanzi, V. 1991. Public Finance in Developing Countries. London: Edward Elgar Publishing.

Tanzi, V. 1996. "Fiscal Federalism and Decentralization: A Review of Some Efficiency and Macroeconomic Aspects." European Journal of Political Economy $24,705-712$.

Teperova, J. and K. Kubantova. 2013. "Omezeni a moznosti jednoho inkasniho mista v Ceské republice." Cesky financni a ucetni casopis 2013(1), 61-76.

Tran-Nam, B., C. Evans, M. Walpole and K. Ritchie. 2000. "Tax Compliance Costs: Research Methodology and Empirical Evidence from Australia." National Tax Journal 53, 229-252.

Vaillancourt, F. 1987. “The Compliance Cost of Taxes on Business and Individuals: A Review of the Evidence." Public Finance 42, 395-414.

Vitek, L. 2008. Ekonomicka analyza zdaneni prijmu. Praha: IREAS.

Vitkova, J. and L. Vitek. 2012. "Spolocenske vyvolane naklady zdaneni." Acta Oeconomica Pragensia 2012(1), 15-30. 